\title{
EDITORIAL
}

\section{$O$ Ministério de Educação e Cultura e o desenvolvimento da enfermagem}

O interesse dos órgãos do Ministério da Educação e Cultura (MEC) pela enfermagem tem sofrido altos e baixos.

Dispositivos da Lei $n .^{\circ} 775 / 49$, a primeira lei que regulou o ensino da enfermagem, colocaram esse ensino sob a égide da Diretoria do Ensino Superior, do então Ministério da Educação e Saúde, que passou a registrar os diplomas de enfermeiro e os certificados de auxiliar de enfermagem e a proceder à verificação dos cursos, para efeito de autorização de funcionamento e reconhecimento.

Em 1956, quando do veto presidencial a um projeto de lei que regulava o ensino da obstetrícia, o Ministro da Educação e Cultura, em obediência à determinação do Presidente da República, contida na justificação do veto, indicou uma comissão para elaborar anteprojeto de lei que incluisse o ensino da enfermagem e obstetrícia, comissão esta composta de enfermeiras e uma obstetriz, cujo trabalho, entretanto, não chegou a ser transformado em lei, em virtude da promulgação da Lei de Diretrizes e Bases da Educação Nacional que modificou totalmente o sistema educacional do País.

Em 1965, em decorrência da nova política do MEC, de procurar o assessoramento de educadores militantes, uma COMISSÃO DE ASSESSORAMENTO DE ENFERMAGEM foi indicada pelo Diretor do Ensino Superior, no mesmo ano substituída por uma COMISSÃO DE ESPECIALISTAS DO ENSINO DE ENFERMAGEM, desig- 
nada pelo Ministro. Esta comissão, a pedido da referida Diretoria, elaborou o trabalho "Subsídio para o desenvolvimento da enfermagem no Plano Decenal", referente ao decênio 1966-1976, a fim de ser entregue ao Ministério do Planejamento. A mesma comissão fez um estudo das escolas de enfermagem, cujo relatório não chegou a ser terminado em virtude da descontinuidade de ação de um Governo para outro.

Foi, entretanto, somente na década de 70 que os técnicos do MEC, mais precisamente os do Departamento de Assuntos Universitários (DAU), órgão que substituiu a Diretoria do Ensino Superior, impressionados com a falta de enfermeiros e o conseqüente desequilíbrio na proporção médico (enfermeiro) passaram a dar à enfermagem a mesma atenção que vinham prestando às demais profissões consideradas prioritárias.

Como passo inicial na concretização desse interesse, o Diretor do DAU indicou um GRUPO DE TRABALHO PARA DIAGNOSTICO DO CURSO DE ENFERMAGEM, composto de educadores de enfermagem, cujo relatório, apresentado em março de 1975, foi o documento inicial que desencadeou uma série de providências para a adequação do curso de enfermagem a demanda do País.

A sua primeira recomendação, referente à necessidade de lotação de enfermeiros no DAU, como assessores para assuntos de educação de enfermagem, foi implementada graças à colaboração da Escola de Enfermagem Ana Neri, da Universidade Federal do Rio de Janeiro, que pôs à disposição daquele órgão duas de suas docentes.

Por iniciativa dessas assessoras, as demais recomendações do documento inicial vêm sendo postas em execução.

Em atenção a uma recomendação relativa à criação de curso de enfermagem nas universidades federais que ainda não contassem com tal ensino, 13 (treze) cursos novos já foram instalados.

Medidas paralelas vêm sendo adotadas, como por exemplo a preparação das coordenadoras dos novos cursos em encontros, cursos de pós-graduação "latu senso" e cursos de Mestrado.

A fim de obter as bases para dar cumprimento a outra recomendação, que diz da conveniência de revisão do "currículo mínimo" 
do Curso de Graduação em Enfermagem e Obstetrícia, o DAU fez um estudo das escolas de enfermagem existentes no País, e promoveu reuniões das assessoras em enfermagem com o Grupo de Trabalho e outras educadoras do ramo. Está em elaboração subsídio para o Conselho Federal de Educação.

O Grupo de Trabalho elaborou, ainda, critérios para verificação de funcionamento e reconhecimento de cursos de enfermagem.

Espera-se que os futuros dirigentes do MEC dêm continuidade a esse programa. Espera-se, também, que os Departamentos de Ensino Médio e de Ensino Supletivo do mesmo Ministério, a exemplo do DAU, focalizem com atenção especial o ensino de enfermagem de $1 .^{\circ}$ e $2 .^{\circ}$ graus, mais do que nunca necessitados de orientação e principalmente de controle.

São Paulo, 22 de novembro de 1977

Maria Rosa Sousa Pinheiro 